\title{
Brucellar Epididymoorchitis: A Report of a Rarely Seen Case at Advanced Age
}

\author{
Fulya Bayındır Bilman'1, Mevliye Yetik¹, Barış Çiçek ${ }^{2}$ \\ ${ }^{1}$ Department of Medical Microbiology, İzmir Menemen State Hospital, İzmir, Turkey \\ ${ }^{2}$ Department of Infectious Disease, İzmir Menemen State Hospital, İzmir, Turkey \\ Email:f_bilman@hotmail.com
}

Received 20 April 2016; accepted 6 May 2016; published 10 May 2016

Copyright (C) 2016 by authors and OALib.

This work is licensed under the Creative Commons Attribution International License (CC BY). http://creativecommons.org/licenses/by/4.0/

CC) (i) Open Access

\begin{abstract}
Although brucellosis is the most common zoonosis all over the world, epididymoorchitis caused by Brucella species is a rarely seen infection. In this report, we present an adult case of epididymoorchitis caused by brucellosis. Patient complained about swollen and painful testicle. Patient had unilateral epididymoorchitis. Brucellosis was diagnosed serologically with lam agglutination test and Coombs Brucella test positivity (1/1280 titer). Patient was treated with rifampicin and doxycycline. In case, complete resolution was achieved with medical treatment and relapse did not occur. Brucellosis should be considered in the differential diagnosis of patients even at old age, presenting with epididymoorchitis in endemic areas.
\end{abstract}

\section{Keywords}

Brucellosis, Epididymoorchitis, Adults

Subject Areas: Infectious Diseases

\section{Introduction}

Brucellosis is a zoonotic disease frequently seen in many societies and known all over the world with its complications [1]. It is reported to be seen as hyper endemic especially in the countries around the Mediterranean Sea [2].

Although its most common finding is arthralgia, infection can invade all organs and in this way complications can be seen in the invaded organs [3]. Its clinical course can be seen in three ways. Acute infection period is the profile presenting symptoms in the first two months after infection. Subacute infection is the profile that occurs when symptoms continue between two months and one year, and chronic infection is the profile happening when the symptoms last more than one year [4]. The most common first period findings are peripheral arthritis and sacroiliitis. Swelling in joints, rash, limited movement and radiological findings direct the diagnosis. In $2 \%$ - 
$20 \%$ of brucellosis patients, prostatitis, epididymoorchitis, cystitis, piyelonephritis, interstitial nephritis, exudative glomerulonephritis and renal abscess can be seen [5]. Epididymoorchitis was defined as swelling and pain in the scrotal dermis, testis and epididymis [6]. Because these symptoms are non-specific, the infections caused by Brucella spp. of urinary system can be disregarded [5]. In patients with epididymoorchitis, granulomatous type inflammation can be seen [4]. Epididymits caused by Brucella spp. can cause severe complications such as necrotizing orchitis, aspermia, and oligospermia if they are not treated.

\section{Case Report}

A 60 years-old man was admitted to urology clinic because of fever up to $38^{\circ} \mathrm{C}$, dysuria, pollakuria, back and legs pain, weakness. He also reported that he had been swollen and painful testicles for more than 10 days but symptoms were not in regress. In the physical examination, swelling and pain in the scrotal dermis, and testis were palpated. Patient had unilateral epididymoorchitis. Other systemic examinations were normal. During this stage results of laboratory tests had been found as follows; white blood cell count $9100 \mathrm{uL}$, erythrocyte sedimentation rate $78 \mathrm{~mm} / \mathrm{h}, \mathrm{C}$ reactive protein: $114.6 \mathrm{mg} / \mathrm{L}$, AST: $13 \mathrm{IU} / \mathrm{L}$, ALT:11 IU/L, hepatitis markers were negative, urinalysis was normally. Patient had a history of unpasteurized dairy product ingestion. Rose Bengal agglutination test (Plasmatec) was performed to patients with suspected brucellosis and result was positive. Antibodies titers of brucellosis were reported as 1:640 in serum with Coombs Brucella (Metser LAB, Turkey) test. Therapy with oral doxycycline (100 mg every $12 \mathrm{~h}$ ) and oral rifampicin (600 mg every $12 \mathrm{~h}$ ) was administered. After 5 days of treatment patient's symptoms were dramatically regressed. Three months after, stopping of the therapy, laboratory tests were as fallows; AST: 17 IU/L, ALT: $21 \mathrm{IU} / \mathrm{L}$, urinalysis was normal and Coombs Brucella (Metser LAB, Turkey) titers of brucella antibodies in serum were subsided to 1:160. After maintenance treatment, all symptoms of the patient were regressed.

\section{Discussion}

Brucellosis transmitted from infected animals to humans, widespread all over the world as zoonosis, is transmitted through consumption of contaminated food, direct inoculation, contact with infected animals, or inhalation of infectious particles [3]. Pasteurization of milk and milk products and procedure of boiling kills Brucella spp. bacilli. The cases where there are transmissions through the breast milk of infected mother and human semen have been reported [7]-[11].

In the areas where it is endemic, the bacteria have been shown to be alive up to eight weeks especially in unpasteurizied white soft cheese [12]. Several serological tests (Rose Bengal, 2-Mercaptoethanol, Wright, Coombs Brucella, Complement fixation and ELISA test) are used for diagnosis of brucellosis [1]. Serological tests are important for both diagnosis and follow-up treatment.Rose Bengal test is traditionally used for rapid screening in many country. In endemic areas, serologic testing is considered to be diagnostic when titers of $1 / 320$ to $1 / 640$ are present, while titers of $1 / 160$ are considered suspicious. The sensitivity and specificity of serologic tests are generally very high for Brucella spp. [13]. Brucella Coombs test titres are a good marker of infection activity independent of disease stage [14].

Kurtaran et al. found epididymoorchitis rate to be 10/136 (7\%) in male group of 136 and average age to be $41 \pm$ 14.7 [15]. Güneş et al., after having probed 15 epididymoorchitis cases between 15 - 51 years of age, reported that the symptom which was the most frequently seen in fifteen cases was testicular pain, the most frequently established finding was scrotal swelling and the most frequently seen laboratory finding was the elevation of the C reactive protein (CRP) [16]. Erdem et al. examined a total of 390 (352 male, 90.2\%) genitourinary brucellosis cases in the multicentric study in which 34 centers were involved [17]. It was reported that in male patients, the most frequent involved site was the scrotal area $(\mathrm{n}=327,83.8 \%)$ as epididymo-orchitis $(\mathrm{n}=204,58 \%)$, orchitis $(\mathrm{n}=112,31.8 \%)$ and epididymitis $(\mathrm{n}=11,3.1 \%)$. Additionally, in female patients, pyelonephritis $(\mathrm{n}=33 / 38)$, $86.8 \%)$ was significantly higher than that in male patients $(n=11 / 352,3.1 \%)$ in this study [17]. Erythrocyte sedimentation rate (ESR) and CRP showed moderate increases. Orchiectomy and abscess drainage had been performed in nine (2.3\%) patients. Erdem et al. detected that therapeutic failure was in $6(1.5 \%)$, relapse occurred in $4(1 \%)$, and persistent infertility related to brucellosis occurred in one patient [17]. Gür et al. detected epididymoorchitis in 14 of 145 male patients [18]. 10/14 (71\%) of these cases are between 15 - 45 years of age. Demiroğlu et al. detected that genitourinary involvement was 5.3\% in 151 brucellosis cases (age range $15-79$ years; 89 female) [19]. In this study, doxycycline + rifampicin combination during six weeks was the most pre- 
ferred one among seven different therapy protocols. A total of 1028 brucellosis cases were evaluated with retrospective analysis over a 10-year period [20]. Buzgan et al. found that acute cases were seen intensively in spring (30.6\%), subacute cases were mainly seen in the autumn (33.8\%). May and September were the peak months of acute cases. Twelve cases $(1.2 \%)$ were found to be seronegative [20]. Genitourinary system involvement was found in $38(3.7 \%)$ patients. Brucella spp. was isolated from semen in a patient who has prostatitis [20]. Epididymoorchitis was observed in 35 cases (3.4\%), being bilateral in three cases. Orchiectomy was performed to three cases because of testicular abscess formation [20].

\section{Conclusion}

We emphasize that the training of society on brucellosis and its complications and the care in medical approach should be increased especially in geographic areas where the disease is endemic. The physicians should follow radiological imaging results and laboratory results about severe complications. Accurate diagnosis rate will increase when serological results positive in low titer and uncommon clinical presentation are closely followed. Additionally, control and eradication of brucellosis depends on the education of farmers, veterinarians and the general public.

\section{References}

[1] Doganay, M. And Aygen, B. (2003) Human Brucellosis: An Overview. International Journal of Infectious Diseases, 7 , 173-182. http://dx.doi.org/10.1016/S1201-9712(03)90049-X

[2] Pappas, G., Papadimitriou, P., Akritidis, N., Christou, L. and Tsianos, E.V. (2006) The New Global Map of Human Brucellosis. The Lancet Infectious Diseases, 6, 91-99. http://dx.doi.org/10.1016/S1473-3099(06)70382-6

[3] Young, E.J. (2005) Brucella Species. In: Mandell, G.L., Bennett, J.E. and Dolin, R., Eds., Principles and Practice of Infectious Diseases, 6th Edition, Churchill Livingstone, Philadelphia, 2669-2672.

[4] Hasanjani Roushan, M.R., Mohrez, M., Smailnejad Gangi, S.M., Soleimani Amiri, M.J. and Hajiahmadi, M. (2004) Epidemiological Features and Clinical Manifestations in 469 Adult Patients with Brucellosis in Babol, Northern Iran. Epidemiology \& Infection, 132, 1109-1114. http://dx.doi.org/10.1017/S0950268804002833

[5] Navarro-Martinez, A., Solera, J., Corredoira, J., Beato, J.L., Alfaro-Martinez, E., Atienzar, M., et al. (2001) Epididymoorchitis due to Brucella melitensis: A Retrospective Study of 59 Patients. Clinical Infectious Diseases, 33, $2017-$ 2022. http://dx.doi.org/10.1086/324489

[6] Colmenero, J.D., Muñoz-Roca, N.L., Bermudez, P., Plata, A., Villalobos, A. and Reguera, J.M. (2007) Clinical Findings, Diagnostic Approach, and Outcome of Brucella melitensis Epididymoorchitis. Diagnostic Microbiology and Infectious Disease, 57, 367-372. http://dx.doi.org/10.1016/j.diagmicrobio.2006.09.008

[7] Kato, Y., Masuda, G., Itoda, I., Imamura, A., Ajisawa, A. and Negishi, M. (2007) Brucellosis in a Returned Traveler and His Wife: Probable Person-to-Person Transmission of Brucella melitensis. Journal of Travel Medicine, 14, 343345. http://dx.doi.org/10.1111/j.1708-8305.2007.00139.x

[8] Williams, E. (1989) Chapter 2: The Mediterannean Fever Commission-Its Origins and Achievements. In: Young, E.J. and Corbel, M.J., Eds., Brucellosis-Clinical and Laboratory Aspects, CRC Press, Boca Raton, 11-24.

[9] Vandercam, B., Zech, F., de Cooman, S., Bughin, C., Gigi, J. and Wauters, G. (1990) Isolation of Brucella melitensis from Human Sperm. European Journal of Clinical Microbiology \& Infectious Diseases, 9, 303-304. http://dx.doi.org/10.1007/BF01968069

[10] Palanduz, A., Palanduz, S., Güler, K. and Güler, N. (2000) Brucellosis in a Mother and Her Young Infant: Probable Transmission by Breast Milk. International Journal of Infectious Diseases, 4, 55-56. http://dx.doi.org/10.1016/S1201-9712(00)90068-7

[11] Chen, S., Zhang, H., Liu, X., Wang, W., Hou, S., Li, T., et al. (2014) Increasing Threat of Brucellosis to Low-Risk Persons in Urban Settings, China. Emerging Infectious Disease, 20, 120-130. http://dx.doi.org/10.3201/eid2001.130324

[12] Corbel, M.J., Beeching, N.J., Fauci, A.S., Braunwald, E., Kasper, D.L., Hauser, S.L., et al. (2008) Brucellosis in Harrison's Principles of Internal Medicine. 17th Edition, Mc Graw-Hill Companies, New York, 973-976.

[13] Gómez, M.C., Nieto, J.A., Rosa, C., Geijo, P., Escribano, M.A., Muñoz, A. and López, C. (2008) Evaluation of Seven Tests for Diagnosis of Human Brucellosis in an Area Where the Disease Is Endemic. Clinical and Vaccine Immunology, 15, 1031-1033. http://dx.doi.org/10.1128/CVI.00424-07

[14] Casanova, A., Ariza, J., Rubio, M., Masuet, C. and Díaz, R. (2009) Brucellacapt versus Classical Tests in the Serological Diagnosis and Management of Human Brucellosis. Clinical and Vaccine Immunology, 16, 844-851. 
http://dx.doi.org/10.1128/CVI.00348-08

[15] Kurtaran, B., Candevir, A., Inal, A.S., Kömür, S., Akyıldız, Ö., Saltoğlu, N., et al. (2012) Clinical Appearance of Brucellosis in Adults: Fourteen Years of Experience. Turkish Journal of Medical Sciences, 42, 497-505.

[16] Güneş, M., Geçit, I., Bilici, S., Demir, C., Özkal, A., Ceylan, K., et al. (2010) Brucellar Epididymo-Orchitis: Report of Fifteen Cases. Van Medical Journal, 17, 131-135.

[17] Erdem, H., Elaldi, N., Ak, O., Gulsun, S., Tekin, R., Ulug, M., et al. (2014) Genitourinary Brucellosis: Results of a Multicentric Study. Clinical Microbiology and Infection, 20, O847-O853. http://dx.doi.org/10.1111/1469-0691.12680

[18] Gür, A., Geyik, M.F., Dikici, B., Nas, K., Çevik, R., Saraç, J. and Hosoglu, S. (2003) Complications of Brucellosis in Different Age Groups: A Study of 283 Cases in Southeastern Anatolia of Turkey. Yonsei Medical Journal, 44, 33-44. http://dx.doi.org/10.3349/ymj.2003.44.1.33

[19] Demiroğlu, Y.Z., Turunç, T., Alişkan, H., Colakoğlu, S. and Arslan, H. (2007) Brucellosis: Retrospective Evaluation of the Clinical, Laboratory and Epidemiological Features of 151 Cases. Mikrobiyoloji Bülteni, 41, 517-527.

[20] Buzgan, T., Karahocagil, M.K., Irmak, H., Baran, A.I., Karsen, H., Evirgen, O., et al. (2010) Clinical Manifestations and Complications in 1028 Cases of Brucellosis: A Retrospective Evaluation and Review of the Literature. International Journal of Infectious Diseases, 14, e469-e478. http://dx.doi.org/10.1016/j.ijid.2009.06.031 